\title{
THE IMPACT OF BENEFITS AND SERVICES ON MANAGER ENGAGEMENT AND MANAGER RETENTION IN TOURISM INDUSTRY: ENHANCED BY THE EFFECT OF MANAGEMENT LEVEL
}

\author{
İpek ALDATMAZ ${ }^{[*]}$ \\ Cansu AYKAC $C^{[*]}$ \\ Ülkü DİCLE ${ }^{[* *]}$
}

\begin{abstract}
Manager engagement and retention are vital to the success and organizational performance of many service sector organisations. Maintaining manager retention is a major challenge that many hotel enterprises face today. It is critical that organizations give greater importance to manager engagement, motivation and retention and therefore establish an efficient benefits and services strategy for retaining these core managers for the persistence and achievement of the organization. Employee motivation and retention have gained even more significance as a result of the heightened dynamism in hotel business within the tourism sector. As the focal point of Turkish economy, recent developments in the tourism and hotel enterprises have caused organizations to accelerate their human resources activities and accordingly more attention has been given to the employee satisfaction practices in this industry. This study, in contrary, aims to identify and study the effect of benefits and services on manager engagement and retention in hotel organizations in Turkey. The study was conducted among three different levels of hotel management, namely, top level, middle level and operational level managers. The results of the study show that while there is a positive and significant relationship between Benefits and Services and Management Engagement, there is no relationship between Benefits and Services and Management Retention.
\end{abstract}

Keywords: Manager Retention, Engagement, Benefits, Services, Tourism, and Hotel Organizations

JEL Classification: L69, M54, J80

[*] İpek Aldatmaz, Yeditepe University,PhD Candidate, ipekald@gmail.com

[**] Cansu Çakır, Yeditepe University, PhD Candidate, cansu.cakir@yeditepe.edu.tr

${ }^{[* *]}$ Prof.Dr.Ülkü Dicle, Yeditepe University, udicle@yeditepe.edu.tr 


\title{
TURIZZM SEKTÖRÜNDE YÖNETİCINİN CEZBEDİLMESİ VE ELDE TUTULMASINDA YAN HAK VE HİZMETLERİN ETKİSI: YÖNETİM DÜZEYLERIYYLE ETKISINIIN ARTIRILMASI
}

\begin{abstract}
Özet
Yöneticinin cezbedilmesi ve elde tutulması hizmet sektöründe faaliyet gösteren birçok şirketin başarısı ve performansı için büyük önem taşımaktadır. Şirketlerin uzun vadeli başarı elde etmesi ise yöneticinin cezbedilmesi, motivasyonu ve elde tutulmasına yönelik etkin yan hak hizmet stratejilerinin belirlenmesi ve çekirdek yöneticilerin devamlılığının sağlanması ile doğrudan ilişkili hale gelmiştir. Turizm ve otelcilik sektöründe artan dinamizme bağlı olarak çalışan bağlılığı ve elde tutulması yönünde yapılan çalışmaların alanı genişlemiş ve bu konuya verilen önem değer kazanmıştır. Türk ekonomisinin can damarını oluşturan turizmcilik alanında gelişimin artmasıyla birlikte bu alanda insan kaynakları uygulamaları ivme kazanmış ve bu doğrultuda iş tatmini sağlayan uygulamalara fazlasıyla yer verilmeye başlanmıştır.

Bu çalışma, Herzberg'in hijyen faktörlerini dikkate alarak, Türkiye'deki otel işletmelerinde yan hak hizmetlerinin yöneticinin cezbedilmesi ve elde tutulması üzerindeki etkisini belirlemeyi ve analiz etmeyi amaçlamaktadır. Araştırmanın kapsamı üç farklı yönetici seviyesinde - üst düzey yönetici, orta düzey yönetici ve bölüm şefi olarak belirlenmiştir. Araştırma sonuçları yan hak hizmetleri ile yöneticinin cezbedilmesi arasında pozitif ve anlamlı bir ilişki olduğunu ortaya koyarken, yan hak hizmetleri ile yöneticinin elde tutulması arasında herhangi bir ilişki olmadığını göstermiştir.
\end{abstract}

Anahtar Kelimeler: Yöneticinin Elde Tutulması, Yöneticinin Cezbedilmesi, Yan hak hizmetleri, Turizm ve Otel Sektörü

JEL Sınıflaması: L69, M54, J80

\section{Introduction}

The main motivation of almost all organizations is to achieve customer satisfaction and organizational performance. Maintaining customer satisfaction not only enhances an organization's profitability, but also supports the development of an organization ${ }^{1}$. It is therefore critical to sustain the satisfaction and commitment of employees to the organization. Employees are considered as the major resource of a company, thus fulfillment of employee requirements by satisfied customers is essential ${ }^{2}$. When employees are satisfied, both organizational performance and customer satisfaction are preserved. Employee motivation and retention have gained even more significance as a result of the heightened dynamism in hotel business within the tourism sector. As the focal point of Turkish economy, recent developments in the tourism and hotel enterprises have caused organizations to accelerate their human resources activities and accordingly more attention has been given to the human resources practices of tourism and hotel industry. In hotel organizations, customer satisfaction and the level of service quality are

1 D. Dubrovski, "The role of customer satisfaction in achieving business excellence" Total quality management, 2001, 12(7-8), 920-925

2 D.Nebeker-L. Busso- P.D. Werenfels-H. Diallo- A. Czekajewski- B. Ferdman, Airline station performance as a function of employee satisfaction. Journal of Quality Management, 2001, 6(1), 29-45. 
largely maintained by the effort of managers. Hence, defining human resources policies properly and engaging and retaining managers are critical for the efficiency and success of these types of organizations.

Research reveals the positive impact of employee satisfaction on customer satisfaction and service quality. The significance of the effect of employee satisfaction on customer satisfaction has relatively increased in service organizations. Since human capital is highly required in service organizations, maximum efficiency is retained through the fulfillment of employees' expectations and the maintenance of working conditions compatible with employees' needs ${ }^{3}$

In the past, while people would be satisfied with the fulfillment of their basic physiological needs, different structures of needs have emerged today ${ }^{4}$. Restructuring has become an essential requirement for organizations due to social complexities in organizations; satisfaction of the needs of both individuals and organizations, stiff competition, restructuring and mergers, developments in management philosophy and country legislation ${ }^{5}$

Tourism industry remains significant with its contributions to the generation of employment opportunities and foreign exchange earnings, hence it is important to understand the requirements and expectations of employees for delivering outstanding service and displaying exceptional performance. Since job satisfaction is the positive behavior obtained by the individual as a result of the work performed, it creates differences based on individual aspects. The degree of satisfaction differs even for identical tasks and time periods due to distinct employee aspects. Thus, factors affecting job satisfaction vary depending on different employee aspects ${ }^{6}$.

According to Herzberg et al. (1959), developments in the workplace are influential on human behavior. Positive developments lead to job satisfaction and negative developments result in dissatisfaction. Satisfaction is the positive feeling individuals develop once they complete their work. The development of positive feelings is dependent on both internal and external factors. Besides, individuals possess different aspects and therefore are satisfied by different factors. Positive behavior, or satisfaction of individuals, positively affects factors such as efficiency, success and maintenance of high quality, fast and good service. Dissatisfaction of individuals lays the ground for the emergence of problems such as absenteeism, tardiness, psychological problems and incompatibility with coworkers. In tourism industry, since generation and consumption of services is performed simultaneously, and one-to-one interaction is practiced, employee satisfaction is a direct reflection on customers ${ }^{7}$. Employees have a direct influence on the customer, and the employee-customer link is a significant reflection of the hotel organization's

3 Ö.Özmen et.al. Otel İşletmelerinde Çalışan Personelin İşin Özelliklerine ve Kişilik Tiplerine Göre İş Doyumlar, 2. Ulusal Turizm Kongresi, Kuşadası: 21/23 Kasım 1991

4 J.Gelb, "Feminism, NGOs, and the impact of the new transnationalism”, Dynamics of Regulatory Change: How Globalization Affects National Regulatory Policies, 2004, p. 298

5 Jeff Snipes "Identifying and cultivating high-potential employees", Chief Learning Officer Magazine, 2005, 4.11: 54-64.

6 Yüksel Öztür- Hüseyin Alkiş, Konaklama Işletmelerinde Çalışanların Iş Tatmininin Ölçülmesi Üzerine Bir Araştırma. Uluslararası Yönetim Iktisat Ve Işletme Dergisi, 2012, 7.14: 437-460. 
achievement. While tourism is central to the economies of many countries, the tourism sector in Turkey has experienced constant and substantial change in the past few decades.

Herzberg's hygiene and motivation theory is a significant tool for analyzing employee satisfaction and retention. Herzberg, in his hygiene-motivation theory, classifies the factors that generate job satisfaction under two groups as motivating (intrinsic) and hygiene (extrinsic) factors ${ }^{7}$. However, there has been moderately less research regarding the determinants of employee engagement and retention using Herzberg's hygiene-motivation theory. Therefore, this paper aims to fill this empirical gap. On the basis of Herzberg's theory, this study aims to focus on the effect of extrinsic motivation tools (hygiene factors) and therefore attempts to examine the relationship between benefits and services and manager engagement and manager retention and the moderating effect of management level on this relationship in the Turkish tourism industry.

\section{Literature Review}

\section{I. Benefits and Services}

Employee commitment to the organization is enhanced by incentives and workplace supports ${ }^{8}$. Employment relationship is an important aspect of commitment; therefore organizations strive to increase employees' perception about organizational support by appreciating their contributions and caring about their employees as individuals ${ }^{9}$. HRM practices aimed at meeting employees' needs and their longer-term development show the type of organizational support employees need for retaining their jobs ${ }^{10}$.

Employee benefits have noticeably increased for the past 20 years as a way to sustain competitive position. Employee benefits packages have become significant elements of the overall compensation package and are likely to enhance job satisfaction ${ }^{11}$. Muse and Wadswoth, argue that "organizations may strategically use benefit packages to send signals to their employees regarding this employment relationship". Employee benefits are classified into two comprehensive categories. Traditional benefits category includes health and life insurance and retirement benefits. Family-friendly benefits category is aimed at responding to different requirements of employees that possess the issue of balancing work, family and personal needs ${ }^{12}$. Muse and Wadswoth make a distinction between the two categories and define "traditional benefits as those that are consistently offered across organizations, and are therefore often expected by employees,

$7 \quad$ F. Eroğlu (a.g.k.)

8 Anne S. Tsui et al., Alternative approaches to the employee-organization relationship: does investment in employees pay off?, Academy of Management journal, 1997, 40.5: 1089-1121.

9 Linda Rhoades- Robert Eisenberger, Robert. Perceived Organizational Support: A Review of The Literature. Journal of Applied Psychology, 2002, 87.4: 698.

10 John R. Deckop et.al., "The effects of CEO pay structure on corporate social performance” Journal of Management, 2006, 32.3: 329-342.

11 Richard White "Employee preferences for nontaxable compensation offered in a cafeteria compensation plan: An empirical study", Accounting Review, 1983, 539-561

12 Gary E. ROBERTS, et al. Traditional and family-friendly benefits practices in local governments: Results from a national survey, Public Personnel Management, 2004, 33.3: 307-330. 
and nontraditional benefits, as those not typically offered by many organizations, and therefore are not expected by employees".

Based on a survey of New Jersey local governments, Roberts (2000) states that traditional benefits are essential to employee job selection and retention issues. Kim and Wiggins (2011) also state the significant impact of traditional benefits on employee satisfaction and turnover intention. According to Social Exchange Theory (SET), traditional benefits can be regarded as positive and helpful activities demonstrated toward employees by the organization as these benefits generate obligations for employees to give back in positive and helpful ways. This may result in employees' job satisfaction and decline in their intention to leave.

In the past, corporate benefit packages, either provided by the company or through collective bargaining agreements, included mostly vacation, sick leave, pension, and retirement items. However, in recent years, 'big ticket items' including health care, childcare, training, and stock options have increasingly become fundamental corporate human resources policies ${ }^{13}$. Salary, free lunch or transportation is not the only motivator for today's workers. Healthcare benefit packages, individual pension, life insurance, work environment and working conditions, supervision, education and training opportunities, ownership in the company, childcare and many others have been regarded more significant and more motivating in today's business world.

Health care plans are considered as the main elements of employee benefit packages because of their perceived value as well as their financial impact. Besides, an equal benefit plan for all levels of employment that was offered by organizations in 1960s is not valid any more and today, benefit compensation varies by position and competence of the employee ${ }^{14}$.

Employees identify training as a benefit due to the fact that competence and knowledge needed for high performance change and develop rapidly and continuously. Workers ensure job security by attaining a wide array of skills through training and this helps employees to be up to date about the changes at work. Many corporations provide their workers partial ownership in the company as a benefit with the belief that employees will share the perspective of the owner by feeling more responsible, motivated and productive at work ${ }^{15}$

Childcare services have been presented to employees as a benefit since the early 1900 s. According to Rodriguez (1983), employers gain some benefits by offering child care services: a more steady human capital, less absenteeism, higher production, enhanced morale, better employer-employee relations, an effective recruitment pool, and a positive public reputation (Haar and Kossack, 1990). Empirical studies have demonstrated the relationship between the existence of family-friendly benefits and enhanced work attitudes and employee retention (Lockwood 2003). Saltzstein, Ting, and Saltzstein (2001) express the positive link between

13 Jerry Haar- Sharon Kossack, Employee benefit packages: How understandable are they?. Journal of Business Communication, 1990, 27.2: 185-200. 
family-friendly benefits and employees' job satisfaction. Besides, Lee and Hong (2011) and Kim and Wiggins (2011) indicate the positive impact of family-friendly benefits on work attitudes and performance. According to the perspective of SET, employees recognize these benefits as "extra." Consequently, employees may feel compelled to exercise "extra" effort in exchange for "extra" benefits.

Benefits packages and other services are means to creating engagement and retaining workers. As competition for talented and qualified managers broaden, it becomes a necessity for organizations to develop, adapt and improve additional motivational tools in order to facilitate satisfaction at work. Both financial and non-financial benefits and services that organizations provide to their managers make the difference in gaining a competitive advantage for engaging, motivating and retaining their workers.

\subsection{Manager Engagement}

Based on a global survey conducted among 656 CEOs, employee engagement is ranked as one of the top five most significant challenges managers encounter. Gallup Workplace Audit (1992-1999) conducted by Gallup organization predicts a cost of more than $\$ 300$ billion in productivity loss alone. As Gallup's engagement ratio is considered as a macro-level indicator of an organization's wellbeing, it permits companies to track the ratio of employees engaged to employees actively disengaged. This ratio for the average working population is approximately 2:1.

The bestselling book, 'First, Break All the Rules', that included Gallup's results on engagement revealed that less than one in every five workers is actively engaged in their work ${ }^{16}$. Britt, Adler, and Bartone (2001) stated that if people engage in meaningful work, this could result in a perception of work benefits. Employee engagement, used by other research in terms of different measures such as involvement and enthusiasm associated engagement to variables such as employee turnover, customer satisfaction-loyalty, safety, and to some extent, productivity and profitability measures ${ }^{17}$. Therefore, there exist practical reasons why organizations should focus on employee engagement at work.

Employee engagement has been defined in many different ways in the academic literature. Kahn (1990:694) describes employee engagement as "the harnessing of organization members' selves to their work roles; in engagement, people employ and express themselves physically, cognitively, and emotionally during role performances". Disengagement is about disconnecting from work roles, in which people uncouple and protect themselves physically, cognitively, and emotionally when performing their jobs (p. 694). Employee engagement in terms of cognition is about employees' beliefs about the organization, the leaders and working conditions. The emotional

16 David Buckingham, "Young people, politics and news media: beyond political socialization", Oxford Review of Education, 1999, 25 1-2, 171-184

17 James K.Harter, et.al., Theodore L. Business-unit-level relationship between employee satisfaction, employee engagement, and business outcomes: a meta-analysis. Journal of applied psychology, 2002, 87.2: 268. 
side refers to the employees' feelings about these three elements and positive or negative behavior toward the organization and its leaders. The physical side of employee engagement involves the physical effort applied by individuals to succeed in their roles. Therefore, according to Kahn (1990), employee engagement is the state of being both psychologically and physically present when acquiring and performing an organizational role.

Nelson \& Simmons (2003) described engagement as the positive feeling employees possess toward their work, consider their work individually meaningful, and their workload as manageable, and have expectation for the potential of the work. Similar to Kahn, May, Gilson, \& Harter (2004) generated a three-dimensional concept of engagement - physical, emotional and cognitive dimensions and engagement has often been described as commitment to the organization both emotionally and intellectually. May et al. (2004) discovered the relationship between meaningfulness, safety, availability and employee engagement. Meaningfulness was positively related to job enrichment and role fit. While safety was positively related to rewarding coworker and supportive supervisor relations, adherence to co-worker norms and self-consciousness showed negative impact. Besides, while psychological availability was related to resources, the effect of participation in outside activities was negative. In general, meaningfulness showed the greatest effect on diverse employee outcomes in terms of engagement. Baumruk (2004), Richman (2006) and Shaw (2005) defined employee engagement as "emotional and intellectual commitment to the organization". According to Frank et al. (2004), "it is the amount of discretionary effort exhibited by employees in their job".

It is important to evaluate levels of employee engagement by occupations, industries and globally. Gallup provides international evidence through its Employee Engagement Index surveys in many countries. However, due to cultural and definitional differences, it is critical to evaluate international comparisons of levels of employee engagement with care. It is therefore stimulating to study some of Gallup's results. Gallup Organization's studies demonstrate the following results - around $20 \%$ of U.S. employees are disengaged, $54 \%$ are neutral and $26 \%$ are actively engaged ${ }^{18}$.

Tower Perrin conducted one of the most extensive studies in engagement area in 2003, 2005, and 2007 and consequently the results have been gathered in a book ${ }^{19}$. The survey included data of 85,000 employees from 16 different countries. Tower Perrin studies demonstrate the following results - $24 \%$ of employees were disengaged, $62 \%$ of employees were moderately engaged, and $14 \%$ of employees were highly engaged ${ }^{20}$.

Towers Perrin (2003) researchers, by conducting a comparison between a series of demographic segments, ranging from job level (senior executive, director/manager, supervisor/foreman, specialist/professional, non-management salaried and non-management hourly) to industry

18 John H. Fleming, et.al., Manage your human sigma, Harvard business review, 2005, 83.7: 106.

19 Julie GEBAUER-Don LOWMAN, Engagement Gap-Practice the 10 drivers of high engagement, Executive excellence, 2009, 26.4: 5 .

20 Towers Perrin “Ten steps to creating an engaged workforce: Key European findings" Towers Perrin global workforce survey 2005, 2006. 
category (non-profit, high tech, heavy manufacturing, insurance, pharmaceuticals, hospital and finance/banking) discovered a pattern within the segments. While highly engaged respondents were just a small group, disengaged group was slightly larger and 'the moderately engaged group' was the majority.

Based on a survey conducted in Thailand in 2005, only $12 \%$ of Thailand's employee population are 'engaged', $82 \%$ are 'actively disengaged' and 6\% are disengaged. Similar results in a Gallup survey (2004) revealed similar results in the levels of engagement in Australia, China, Japan, New Zealand and Singapore to be 18 per cent, 12 per cent, 9 per cent, 17 per cent and 9 per cent respectively ${ }^{21}$.

Herzberg's (1959) two-factor theory, with its notional background, constitutes the foundation of this study. Herzberg claimed that employee motivation is higher when backed up with intrinsic values rather than extrinsic values. Motivation is formed by internal factors and driven by factors that are more associated with the intrinsic values of the work, which Herzberg refers to as motivators. Herzberg's intrinsic factors involve success, appreciation, responsibility, progress and growth. In contrary, some factors lead to employee dissatisfaction that mostly emerge due to external, non-work relevant variables. These factors, also named as hygiene factors do not generate motivation but must be existent in the workplace to attain content employees. Hygiene factors involve company policies, salary, co-worker relations, and the styles of supervisors ${ }^{22}$. Herzberg (1959) as mentioned in Bassett-Jones and Lloyd's (2005) study further discussed that removing the factors of dissatisfaction via hygiene factors would not cause satisfaction but instead would create a neutral situation. The motivation arises merely within the practice of intrinsic factors.

However, empirical findings (eg. Kinnear and Sutherland, 2001; Meudell and Rodham, 1998; Maertz and Griffeth, 2004) displayed that extrinsic values such as salary, personal relationships, pleasant working setting, and work safety are regarded as motivational factors by employees that affected their stay in the organization. The inference is that management should not just depend on intrinsic values to motivate and engage employees, and instead a blend of both motivating and hygiene factors should be recognized as an applicable retention strategy. Gallup has tremendous amount of evidence for the measurements of the level employee engagement and required organizational results ${ }^{23}$. There may be other notion-based instruments or facilitators, which could aid describe and increase value for the relationship between employee engagement and success of manager effectiveness in modern organizations. As managers' effectiveness and success largely depend on the engagement of managers in the hotel business, the factors that affect their engagement in terms of extrinsic variables should be evidently diagnosed. Based on

21 THE GALLUP ORGANIZATION, www.gallup.com, Accessed (28th June 2007)

22 Bassett-Jones, et.al, Does Herzberg's motivation theory have staying power?, Journal of management development, 2005, 24.10:929-943

23 Marcus Buckingham-Curt Coffman, First, break all the rules: What the worlds greatest managers do differently, Simon and Schuster, 1999. 
these empirical studies, we state the hypothesis that benefits and services as an extrinsic variable, impacts the level of the engagement of managers in tourism industry in Turkey;

\section{$\mathrm{H}_{1}$ : There is a positive and significant relationship between Benefits and Services and Manager Engagement \\ $\mathrm{H}_{2}$ : There is a moderating effect of management level on the relationship between Benefits and Services and Manager Engagement}

\subsection{Manager Retention}

The current global environment has transformed significantly and this change still continues. Globalization, technological innovation, and increasing global competition force companies to focus on their competitive edge ${ }^{24}$. The rising global competition for the 'best' employees due to the shortage of new workforce entering in various industrial economies lead companies to guarantee their employees' stay within the organization in order to obtain a competitive edge. Yet, most employees today do not require a conventional career within an organization ${ }^{23}$. As a result, employees are now less loyal and more opportunistic in comparison to the workers of the past ${ }^{25}$. SD Worx, a human resource and payroll company in Belgium, provided that while in 2007 employee turnover rate was approximately 17.46\%, this rate was 39\% (SD Worx 2008) for employees younger than 25. This statistic demonstrates that new generation employees at work do not possess or want a conventional career within the same organization as their older colleagues do and probably have other career options in other organizations ${ }^{26}$.

The term retention has been defined as "an obligation to continue to do business or exchange with a particular company on an ongoing basis" 27 . A wider description of retention has been stated as "customer liking, identification, commitment, trust, readiness to recommend, and repurchase intentions, with the first four being emotional-cognitive retention constructs, and the last two being behavioral intentions" 28 .

Employee retention has been regarded essential for the growth and achievement of organizational goals and objectives ${ }^{29}$. Employees are encouraged to stay with the organization either for a

24 Ronald J. Burke- Eddy Ng, The changing nature of work and organizations: Implications for human resource management. Human Resource Management Review, 2006, 16.2: 86-94.

25 Jean-Marie Hiltrop, “The quest for the best: human resource practices to attract and retain talent" European Management Journal, 1999, 17.4: 422-430.

26 Eva Kyndt, et al. "Employee retention: Organisational and personal perspectives”, Vocations and Learning, 2009, 2.3: $195-215$.

27 Mosad Zineldin, "Beyond relationship marketing: technologicalship marketing”, Marketing Intelligence \& Planning, 2000, 18.1: 9-23.

28 Bernd Stauss, et al. "Retention effects of a customer club", International Journal of Service Industry Management, 2001, 12.1: 7-19.

29 Frederick F. Reichheld, Loyalty rules!: How today's leaders build lasting relationships, Harvard Business Press, 2001. 
lengthy period or throughout the course of a term-based project. The most valued resource of all businesses is possibly a steady and dedicated workforce. A steady workforce creates a competitive advantage for organizations due to unsteady and volatile work environment.

Organizational culture, communication, strategy, pay and benefits, flexible work schedule and career development systems are the factors that lead to retention and therefore should be managed in a consistent manner. Researchers often investigate the effect of benefits on retention. Maccoby (1984), for five years, observed Bell system employees' and supervisors' job satisfaction and saw that their satisfaction with their pay and benefits resulted in their motivation to work efficiently.

The descending situation of the national economy has brought into perspective the significance of human resources and employee retention. The human resource policy model ${ }^{30}$ in strategic human resource management indicates that creating an employee benefit management practice supports retention if this practice is consistent with the higher-level concept of family-friendly policy. Wagar and Rondeau (2006) observed a relationship between the implementation of particular HRM practices and employee retention in SMEs. They discovered that several HRM practices - selection techniques, employee assistance programs, and formal training and compensation packages increase employee retention.

Research studies have proved that organizations with effective retention policies and practices will receive worker commitment and efficiency. Organizations engaged in different strategies, other than pay and benefits, can attract and retain their employees. Recognition, flexible work arrangements, work-life balance, employee engagement, health and safety, communication, workplace diversity, formal wellness programs, inclusion and employee development are some examples of several retention strategies ${ }^{31}$. Compensation is considered as one of the most important issues in attracting and keeping talented people in organizations. Parker \& Wright (2001) puts forward the hypothesis that, money, by shaping attitudes, influences employee behavior. Thus, wages are influential on the attraction and retention of employees ${ }^{32}$. Delivering an advantageous remuneration package is a widely discussed aspect of employee retention.

There are seven factors that can augment employee retention ${ }^{33}$ : (i) compensation and appreciation of the performed work, (ii) provision of challenging work, (iii) chances to be promoted and to learn, (iv) invitational atmosphere within the organization, (v) positive relations with colleagues, (vi) a healthy balance between the professional and personal life, and (viii) good communications. These factors together propose an array of norms and practices in the workplace that may be considered as attracting employee engagement. Other factors such as integrity and involvement

30 Motohiro morishima, "The evolution of white-collar human resource management in Japan", Advances in industrial and labor relations, 1996, 7: 145-176.

31 L. Kinnear- M. Sutherland, Money is fine but what's the bottom-line?.People Dynamics, 2001, 19.1: 14-19.

32 Owen Parker-Liz Wright, pay and employee commitment: The missing link-the company that enhances compensation conditions and practices will likely see an improvement in employee commitment. Ivey Business Journal, 2001, 65.3: 70-73.

33 Joan Leslie Walker, Extended discrete choice models: integrated framework, flexible error structures, and latent variables. 2001 (PhD Thesis. Massachusetts Institute of Technology) 
of the manager, empowerment, responsibility, and new opportunities/challenges also affect employee retention ${ }^{34}$. Ultimately, other researchers have approved the effect of work experience and tenure ${ }^{35}$.

While rewards are useful in organizations in the sense that they meet financial and material needs, they are also important since they deliver social status and position of power in the organization. According to Allen, Shore and Griffeth (2003), differentiating from others in compensation strategies results in employee attraction and retention. A proper compensation strategy of an organization should be able to attract qualified employees, retain appropriate employees and also provide equity among its employees ${ }^{36}$.

If an organization offers competitive, market-related remuneration and benefits, it can be successful in its retention plan and therefore can motivate its employees for organizational commitment ${ }^{37}$. Mercer (2003) in his study reports that employees will stay within the company if rewarded and may leave if they are weakly rewarded. Employees tend to remain in organizations when their competences, contributions and hard work are appreciated. If a compensation package is utilized as part of a retention plan, internal and external equity should be maintained in remuneration.

In hospitality business, basic determinants of service quality are employees. It is required to maintain a high level of job satisfaction to yield efficiency and organizational cohesion in organizations where service is related to employees ${ }^{38}$. An organization's compensation system and what it offers to its employees plays a significant role in determining their level of commitment and retention.

Herzberg (1959) indicated that hygiene factors were as essential as any other form of employee continuation strategy. However, these factors were not enough for employees to be satisfied or motivated as they formed the bases of dissatisfaction rather than satisfaction. Countless researches have been conducted to study Herzberg's theory within various businesses, people, societies, demographic variables, and many other approaches. The studies revealed contradictory findings (e.g.Malik, and Naeem, 2012; Teck-Hong, and Waheed, 2011). Contrary to Herzberg, Maidani's (1991) research outcomes showed that both hygiene factors and motivation factors were causes of satisfaction. Onen and Maicibi (2004) with their study including 267 non-academic employees of Makerere University in Africa revealed that remuneration (basic salary and allowance) as part of hygiene factors was not considered dissatisfying but actually motivating. Win (2006) also studied

34 Thomas W BRITT, et.al, "Deriving benefits from stressful events: the role of engagement in meaningful work and hardiness". Journal of occupational health psychology, 2001, 6.1: 53.

35 Hugh Gunz-Sally Gunz, Hired professional to hired gun: An identity theory approach to understanding the ethical behaviour of professionals in non-professional organizations. Human Relations, 2007, 60.6: 851-887.

36 Sharon Ruvimbo Terera- Hlanganipai Ngirande, The impact of rewards on job satisfaction and employee retention. Mediterranean Journal of Social Sciences, 2014, 5.1: 481.

37 Thomas Lockwood- Thomas Walton, Building design strategy: using design to achieve key business objectives, Skyhorse Publishing, Inc., 2013.

38 Dilaver Tengilimoğlu, "Hizmet işletmelerinde liderlik davranışları ile iş doyumu arasındaki ilișkinin belirlenmesine yönelik bir araştırma”, Ticaret ve Turizm Eğitim Fakültesi Dergisi, 2005, 1.24: 23-45. 
the effect of Herzberg's two factors on nurses in Taiwan and Myanmar and discovered that the job satisfaction of the nurses in both countries was linked to intrinsic factors. The study also demonstrated that their satisfaction was also related to extrinsic factors. Park (2007) stated that extrinsic factors could be converted to an intrinsic factor as this could create a positive impact on job involvement. According to Tan \& Waheed's (2011) study conducted among salespeople in Malaysia, hygiene factors were more important for job satisfaction compared to motivators and that the only essential motivator was recognition. Besides, remuneration had a mediating role for the relationship between motivation and job satisfaction. Based on the variation of these research results, we state the hypothesis that benefits and services as hygiene factors are motivators and impact manager retention in tourism industry in Turkey;

$\mathrm{H}_{3}$ : There is a positive and significant relationship between Benefits and Services and Manager Retention

$\mathrm{H}_{4}$ : There is a moderating effect of management level on the relationship between Benefits and Services and Manager Retention

Figure I: Proposed Research Mode

According to literature review our proposed research model is,

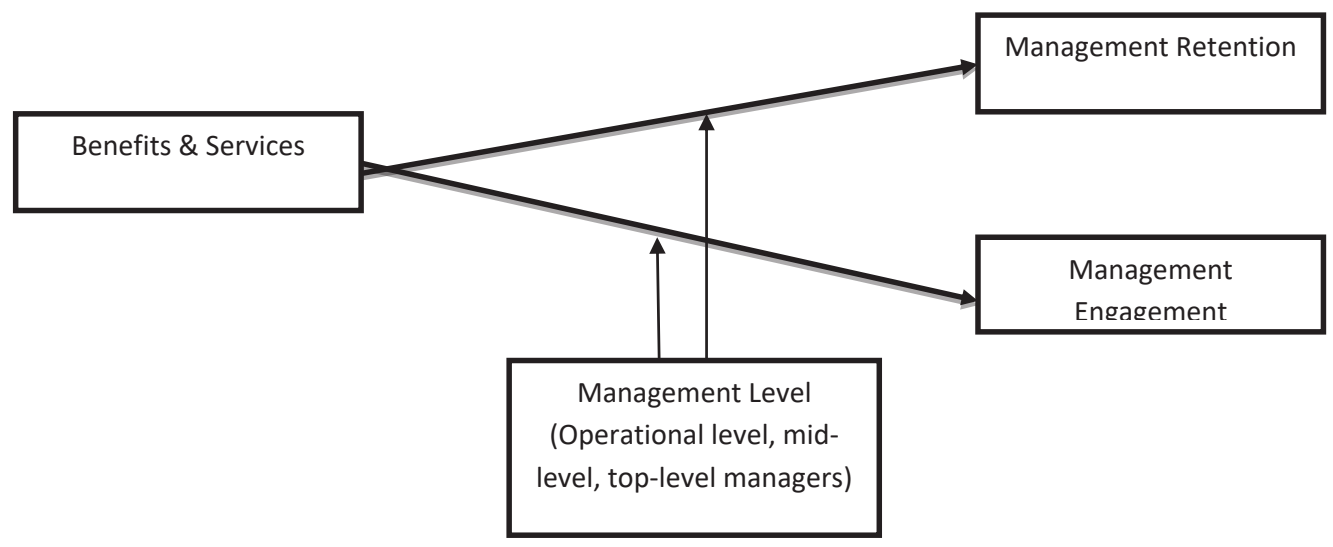

\section{Research Design and Methodology}

The target population of this study is limited to the tourism sector. The study was conducted among hotel managers and survey questions were directed to three levels of hotel management - top level, middle level and operational level managers. We conducted our study in the tourism industry due to increased levels of human resources activities and high employee turnover rates 
in recent years. The data collection period started in October 2015 and ended in December 2015. Data collection instrument consists of three parts: Benefits and Services, Manager Engagement and Manager Retention. The Gallup Workplace Audit, Gallup q12 ${ }^{39}$ was utilized for Manager Engagement survey. For Manager Retention, instrument developed by Eva Kyndt \& Filip Dochy \& Maya Michielsen \& Bastiaan Moeyaert, (Organisational and Personal Perspectives, 2009, Vocations and Learning) was used. For Benefits and Services, a survey was constructed by the authors of this study.

In order to fulfil the research purpose, a quantitative study was adopted and a Six-point (1 - 6) likert scale instrument (strongly agree to strongly disagree) was used. An online questionnaire was forwarded to HR managers of hotels in Turkey. HR managers, who confirmed that their employees respond to the survey, sent the online questionnaire to three levels of managers in their hotels. SPSS 20.0 was used to perform the required test of descriptive statistics, factor and reliability analysis, and multiple regression analysis.

A sample of 122 respondents was reached where 20,5\% (25) of the managers were operational level, $38,5 \%$ (47) of the managers were middle level managers and $41 \%$ (50) were top level managers. The average age was 39 years old and most of the respondents were male with $77.9 \%$ (95).

\section{Research Findings}

In order to reduce the number of our variables, we conducted principle component analysis and created new components. In order to measure the internal consistencies of these components, we conducted reliability analysis.

\section{I Factor and reliability analysis for Benefits and Services}

Table 1 and table 2 shows the results of factor analysis of Benefits and Services. Benefits and Services instrument's KMO and Bartlett's test results are found to be admissible, that means the data used in the analysis was collected homogeneously and there are significant correlations between some variables. At first, there were 15 items but after performing factor analysis, the scale was decreased to 10 items and pooled into 4 components which explain $65,12 \%$ of the total variance of Benefits and Services. Following the reliability analysis, we ended up with these four components that have internal consistency: Insurance Benefits, Workplace Benefits, Family Benefits, and Flexible Shift Benefits.

39 Marcus Buckingham-Curt Coffman, First, break all the rules: What the worlds greatest managers do differently, Simon and Schuster, 1999. 
Table I: The factor analysis results of Benefits and Services

\begin{tabular}{|c|c|c|c|c|}
\hline \multicolumn{5}{|c|}{ Rotated Component Matrix } \\
\hline \multirow{2}{*}{$\begin{array}{l}\text { Question } \\
\text { Number }\end{array}$} & \multicolumn{4}{|c|}{ Component } \\
\hline & 1 & 2 & 3 & 4 \\
\hline$B \& S 1$ & \multirow{12}{*}{$\begin{array}{l}\text {,897 } \\
\text { 863 } \\
\text { 655 }\end{array}$} & \multirow{12}{*}{$\begin{array}{l}, 818 \\
\text {,796 } \\
\text {,632 }\end{array}$} & \multirow{12}{*}{$\begin{array}{l}, 877 \\
, 820\end{array}$} & \multirow{12}{*}{$\begin{array}{l}, 726 \\
, 659 \\
, 637 \\
433\end{array}$} \\
\hline B\&S 4 & & & & \\
\hline B\&S 3 & & & & \\
\hline B\&S13 & & & & \\
\hline B\&S14 & & & & \\
\hline B\&S5 & & & & \\
\hline B\&S8 & & & & \\
\hline B\&S12 & & & & \\
\hline B\&S11 & & & & \\
\hline B\&S9 & & & & \\
\hline B\&S10 & & & & \\
\hline B\&S6 & & & & \\
\hline$\%$ of Variance & 19,64 & 16,94 & 14,32 & 14,22 \\
\hline
\end{tabular}

Table 2: The factor and reliability analysis results summary of Benefits and Services

\begin{tabular}{|l|c|c|c|c|c|}
\hline $\begin{array}{l}\text { Number of } \\
\text { Components }\end{array}$ & C1 & C2 & C3 & C4 & Total \\
\hline \%Explained Variation & 19,642 & 16,942 & 14,319 & 14,217 & $\mathbf{6 5 , 1 2 \%}$ \\
\hline Labels of Components & Insurance Benefits & $\begin{array}{l}\text { Workplace } \\
\text { Benefits }\end{array}$ & Family Benefits & Flexible Shift Benefits & \\
\hline $\begin{array}{l}\text { Components of } \\
\text { Variables within Each } \\
\text { Component }\end{array}$ & $\begin{array}{l}\text { Health Insurance } \\
\text { Family Health Insurance } \\
\text { Life Insurance }\end{array}$ & $\begin{array}{l}\text { Rest Period } \\
\text { Transportation } \\
\text { Compassionate Leave }\end{array}$ & $\begin{array}{l}\text { Child Day-Care } \\
\text { Child Education }\end{array}$ & $\begin{array}{l}\text { Extra Shifts Pay } \\
\text { Flexible Shifts }\end{array}$ & \\
\hline Cronbach Alpha & $\mathbf{0 , 8 1 6}$ & $\mathbf{0 , 6 9 5}$ & $\mathbf{0 , 6 8 9}$ & $\mathbf{0 , 6 2 0}$ & \\
\hline
\end{tabular}

\subsection{Factor and reliability analysis for Manager Engagement and Manager Retention}

Table 3 shows the results of factor analysis of both Manager Engagement and Manager Retention. According to factor analysis results, both instruments' KMO and Bartlett's test results are found 
to be admissible, that means the data used in the analysis was collected homogeneously and there are significant correlations between some variables and both of the instruments conclude in one component. Manager Engagement instrument has 12 items but after performing factor analysis, the scale was decreased to 9 items and a single component with an explained variance of 56\%. Moreover, Manager Retention scale includes 11 items, but after conducting factor analysis, it was observed that 4 items had lower loadings and the scale was decreased to 7 items. For Manager Retention, explained variance is $56 \%$.

Table 3: The factor and reliability analysis results of Manager Engagement and Manager Retention

\begin{tabular}{|l|c|c|}
\hline & Manager Engagement & Manager Retention \\
\hline KMO & 0,868 & 0,840 \\
\hline Bartlett sig. & 0,000 & 0,000 \\
\hline Total variance Explained & $56 \%$ & $56 \%$ \\
\hline Cronbach alpha & 0,900 & 0,794 \\
\hline
\end{tabular}

\subsection{Convergent and Discriminant Validity Analysis}

To investigate the convergent and divergent validity of our questionnaire, we conducted correlation analysis. Convergent validity is an evidence of all components on the same construct. However, discriminant validity represent the evidence that measured constructs are not related to each other.

As shown in table 4, correlation co-efficiencies are higher than 0,5 so the benefits and services questionnaire have convergent validity and benefits and Services questionnaire components are related.

Table 4: Convergent Validity Results of Benefits and Services Components

\begin{tabular}{|l|l|c|c|c|c|}
\hline & \multicolumn{1}{|c|}{$\begin{array}{c}\text { Insurance } \\
\text { Benefits }\end{array}$} & $\begin{array}{c}\text { Workplace } \\
\text { Benefits }\end{array}$ & Family Benefits & $\begin{array}{c}\text { Flexible Shift } \\
\text { Benefits }\end{array}$ \\
\hline $\begin{array}{l}\text { Insurance } \\
\text { Benefits }\end{array}$ & $\begin{array}{l}\text { Correlation } \\
\text { Coefficiencies }\end{array}$ & 1 &, 609 &, 667 &, 596 \\
\hline $\begin{array}{l}\text { Workplace } \\
\text { Benefits }\end{array}$ & $\begin{array}{l}\text { Correlation } \\
\text { Coefficiencies }\end{array}$ &, $\mathbf{6 0 9}$ & 1 &, 636 &, 666 \\
\hline Family Benefits & $\begin{array}{l}\text { Correlation } \\
\text { Coefficiencies }\end{array}$ &, $\mathbf{6 6 7}$ &, 636 & 1 &, 512 \\
\hline $\begin{array}{l}\text { Flexible Shift } \\
\text { Benefits }\end{array}$ & $\begin{array}{l}\text { Correlation } \\
\text { Coefficiencies }\end{array}$ &, $\mathbf{5 9 6}$ &, 666 &, 512 & 1 \\
\hline
\end{tabular}


As shown in table 5, correlation co-efficiencies between workplace benefits and employee engagement are less than 0,5 so there is a discriminant validity and constructs are not related to each other $\left(\mathbf{r}_{\mathrm{FSB}, \mathrm{EE}}=, 336, \mathbf{r}_{\mathrm{FSB}, \mathrm{ER}}=, 113, \mathbf{r}_{\mathrm{WpB}, \mathrm{EE}}=, 438, \mathbf{r}_{\mathrm{WpB}, \mathrm{ER}}=, 102\right)$.

Table 5: Discriminant Validity Results of Variables

\begin{tabular}{|l|l|c|c|c|c|}
\hline & & $\begin{array}{c}\text { Flexible Shift } \\
\text { Benefits }\end{array}$ & $\begin{array}{c}\text { Workplace } \\
\text { Benefits }\end{array}$ & $\begin{array}{c}\text { Emloyee } \\
\text { Engagement }\end{array}$ & $\begin{array}{c}\text { Emloyee } \\
\text { Retention }\end{array}$ \\
\hline $\begin{array}{l}\text { Flexible Shift } \\
\text { Benefits }\end{array}$ & $\begin{array}{l}\text { Correlation } \\
\text { Coefficiencies }\end{array}$ & 1 &, 666 &, 336 &, 113 \\
\hline $\begin{array}{l}\text { Workplace } \\
\text { Benefits }\end{array}$ & $\begin{array}{l}\text { Correlation } \\
\text { Coefficiencies }\end{array}$ &, 666 & 1 &, 438 &, 102 \\
\hline $\begin{array}{l}\text { Emloyee } \\
\text { Engagement }\end{array}$ & $\begin{array}{l}\text { Correlation } \\
\text { Coefficiencies }\end{array}$ &, 336 &, 438 & 1 &, 198 \\
\hline $\begin{array}{l}\text { Emloyee } \\
\text { Retention }\end{array}$ & $\begin{array}{l}\text { Correlation } \\
\text { Coefficiencies }\end{array}$ &, 113 &, 102 &, 198 & 1 \\
\hline
\end{tabular}

\subsection{Hypothesis Testing}

$\mathrm{H}_{1}$ : There is a positive and significant relationship between Benefits and Services and Manager Engagement

To find the significant relationship between benefits and services and manager engagement, we conducted regression analysis. However, among the components of benefits and services, only workplace benefits component demonstrated a higher linearity with regards to manager engagement. Therefore, we continued our analysis with workplace benefits and all other regression assumptions were approved.

Table 6: Regression analysis results for Benefits and Services and Manager Engagement

\begin{tabular}{|l|c|c|c|}
\hline \multicolumn{4}{|c|}{ Dependent Variable: Manager Engagement } \\
\hline Independent variable & Beta & t value & p value \\
\hline Workplace Benefits &, 638 & 8,804 &, 000 \\
\hline $\mathbf{R}=\mathbf{0 , 6 3 8}$ & Adj. $\mathrm{R}^{2}=\mathbf{0 , 4 0 2}$ & $\mathrm{F}=\mathbf{7 7 , 5 1 1}$ & $\mathrm{p}=\mathbf{0 , 0 0 0}$ \\
\hline
\end{tabular}

Regression analysis results exhibit that the model is valid and there is a positive and significant relationship between workplace benefits (sub dimension of benefits and services) and manager engagement. The explanatory power of the model is $40 \%$.

$\mathrm{H}_{2}$ : There is a moderating effect of management level on the relationship between Benefits and Services and Manager Engagement 
To find the moderating role of management level (operation level, mid-level, and top level managers) on the relationship between benefits and services and manager engagement, we used regression analysis. In light of the results of Hypothesis 1, we continued our analysis with workplace benefits. The moderator variable was measured using a categorical scale, i.e., dummy variables, and we chose mid-level managers as a reference value.

Table 7: Regression results to test the moderating role of management level on the relationship between benefits and services and manager engagement

\begin{tabular}{|l|c|c|c|}
\hline \multicolumn{4}{|c|}{ Dependent Variable: Manager Engagement } \\
\hline Independent variable & Beta & t value & p value \\
\hline Workplace Benefits &, 600 & 8,324 &, 000 \\
\hline $\begin{array}{l}\text { Workplace Benefits* } \\
\text { Operational Level Manager }\end{array}$ &, 156 & 2,022 &, 046 \\
\hline Workplace Benefits*Upper Level Manager &, 196 & 2,530 &, 013 \\
\hline $\mathbf{R}=\mathbf{0 , 6 6 7}$ & Adj. $\mathbf{R}^{2}=\mathbf{0 , 4 3 0}$ & $\mathrm{F}=\mathbf{2 9 , 6 8 9}$ & $\mathrm{p}=\mathbf{0 , 0 0 0}$ \\
\hline
\end{tabular}

Regression analysis results exhibit that the model is valid and management level has a moderating effect on the relationship between workplace benefits (sub dimension of benefits and services) and employee engagement. The explanatory power of the model is $43 \%$.

$\mathrm{H}_{3}$ : There is a positive and significant relationship between Benefits and Services and Manager Retention

For employee benefits and services, only flexible shift benefits show a higher linearity between employee retention and other components were eliminated. We continued our analysis with flexible shift benefits and all other regression assumption were provided.

Table 8: Regression analysis results for Benefits and Services and Manager Retention

\begin{tabular}{|l|c|c|c|}
\hline \multicolumn{4}{|c|}{ Dependent Variable: Employee Retention } \\
\hline Independent variable & Beta & t value & p value \\
\hline Flexible Shift Benefits &, 113 & 1,163 &, 248 \\
\hline $\mathbf{R}=\mathbf{0 , 1 1 3}$ & Adj. $\mathbf{R}^{2}=\mathbf{0 , 0 0 3}$ & $\mathrm{F}=\mathbf{1 , 3 5}$ & $\mathrm{p}=\mathbf{0 , 2 4 8}$ \\
\hline
\end{tabular}

According to table 6 , the model is not valid $(\mathrm{p}=0,248)$ and there is no relationship between flexible shift benefits (sub dimension of benefits and services) and manager retention.

$\mathrm{H}_{4}$ : There is a moderating effect of management level on the relationship between Benefits Services and Manager Retention 
To find the moderating role of management level on the relationship between benefits and services and manager engagement, we used regression analysis. According to Hypothesis 2, we continued our analysis with flexible shift benefits. The moderator variable was measured using a categorical scale, i.e., dummy variables, and we chose mid-level managers as a reference value.

Table 9: Regression results to test the moderating role of management level on the relationship between benefits and services and manager retention

\begin{tabular}{|l|c|c|c|}
\hline \multicolumn{4}{|c|}{ Dependent Variable: Manager Retention } \\
\hline Independent variable & Beta & t value & p value \\
\hline Flexible Shift Benefits &, 066 &, 597 &, 552 \\
\hline $\begin{array}{l}\text { Flexible Shift Benefits } \\
{ }^{*} \text { Operational Level Manager }\end{array}$ &, 001 &, 010 &, 992 \\
\hline $\begin{array}{l}\text { Flexible Shift Benefits } \\
{ }^{*} \text { Upper Level Manager }\end{array}$ &, 218 & 2,021 &, 046 \\
\hline $\mathbf{R}=\mathbf{0 , 2 4 1}$ & Adj. $\mathbf{R}^{2}=\mathbf{0 , 0 3 1}$ & $\mathrm{F}=\mathbf{2 , 1 0 2}$ & $\mathrm{p}=\mathbf{0 , 1 0 5}$ \\
\hline
\end{tabular}

According to table 6 , the model is not valid $(\mathrm{p}=0,105)$ and management level does not have a moderating effect on the relationship between flexible shift benefits (sub dimension of benefits and services) and management retention.

\section{Discussions and Conclusion}

Tourism and hospitality sectors, with their increasing importance, provide large contributions to the Turkish economy. Inelmen, Zeytinoglu and Uygur (2012) state that in 2010, Turkey ranked as seventh worldwide by attracting 27 million tourists, and generating $\$ 23$ billion in revenues and ranking tenth worldwide. This increase in the number of tourists may result in a shortage of skilled, motivated and committed employees ${ }^{40}$. When an organization loses its critical employees, and in particular if it loses the knowledge when they leave, this creates huge economic impact on the organization. This knowledge is the knowledge that is utilized to respond to the needs and expectations of the clients. Knowledge management, through creating, capturing and using knowledge fosters an organization's performance ${ }^{41}$. Within each 10 managerial level and professional level employee leaving the organization, a typical company loses around $\$ 1$ million ${ }^{42}$. The total cost of an exempt employee turnover, including both

40 Bob Brotherton, et.al., "Developing human resources for Turkey's tourism industry in the 1990s",Tourism Management, 1994, 15.2: 109-116..

41 Laurie J. Bassi, “Harnessing the power of intellectual capital”, Training \& Development, 1997, 51.12: 25-31.

42 Jac Fitzenz, "It's costly to lose good employees”, Workforce, 1997, 76.8: 50-51. 
direct and indirect costs, are comprised of minimum one-year's pay plus benefits or maximum two-years' pay plus benefits.

This study, conducted among hotel managers in Turkey, examined the relationship between benefits and services, and manager engagement and manager retention, moderated by management level. The study of the relationship contributes to literature as manager engagement is rather a different term and has not been frequently linked to benefits and services in earlier studies.

The results of the study suggested that benefits and services within the context of extrinsic motivation tools are effective in engaging managers. In our study, benefits and services was measured with its four components - insurance benefits, workplace benefits, family benefits, flexible shifts benefits. The most affecting factor for engagement is workplace benefits, yet insurance benefits, family benefits and flexible shifts benefits are insignificant to manager engagement. Besides, the results of the tests suggested that management level positively moderates the relationship between workplace benefits and manager engagement and that middle level managers have higher moderating effect on this relationship. As any changes in benefits and services will create changes in manager engagement, hotel employers should consider the effect of workplace benefits on engagement and then produce policies and strategies accordingly.

In contrary, benefits and services within the context of extrinsic motivation tools are not effective in retaining managers. While the respondents considered flexible shifts benefits important for retention, the tests suggested no significant relationship between benefits and services and manager retention, thus benefits and services do not have any impact on manager retention. Besides, there is no moderating effect of management level on retention.

Herzberg's Two-Factor Theory was used as the theoretical foundation of this study. According to Herzberg, benefits and services are not motivators. They are simply hygiene factors (must, essential) and they do not have motivating effect. In this study, we expected to find a significant relationship between benefits and services and manager engagement and manager retention. However, as opposed to our expectation, benefits and services did not demonstrate any impact on manager retention in Turkey. Thus our findings support Herzberg's theory and also are similar to the findings of many developed countries - findings of Mottaz- DeVoe \& Iyengar and Brislin et.al. This shows that the trend in Turkey has changed and the relative importance of benefits and services has truly diminished. It can be concluded that benefits and services are not the only factors important in ensuring manager retention. While hygiene factors are essential for avoiding manager disengagement, they are not enough for retaining managers in hotel organizations. Therefore, it is essential to conduct a study to investigate the effect of motivating (intrinsic) factors on manager engagement and manager retention and then establish strategies based on the existence of the findings. 


\section{Implications}

Every organization looks for various motivation strategies in order to engage and retain their employees for better organizational results. Both intrinsic and extrinsic motivation tools are considered as the most effective strategies utilized by organizations for manager motivation. Investing in managers is essential for organizational performance; otherwise, managers will become disengaged and this will increase turnover and efficiency will decline in the organization leading to reduced customer loyalty and decreased stakeholder value. Since the cost of poor manager engagement and retention will be harmful for the continuity and success of any hotel enterprise, it is imperative for hotel employers to adopt workplace policies and practices that emphasize management welfare and content.

Results of this study provide guidance to hotel employers who are concerned about customer satisfaction and enhancing the organization's performance. Customer satisfaction and productivity rises when managers are provided with the right motivation tools. Therefore, hotel organizations should motivate their managers both intrinsically and extrinsically to engage them in their work. While a direct relationship between benefits and services (hygiene factors) and manager engagement was found, further analysis is needed to better understand the contributing factors to manager engagement and retention, and to discover the degree to which different incentives, or motivational tools influence hotel management.

This study provides some significant contributions to decision makers in hotel establishments. It might assist hotel employers to conduct further research for management implications. It might aid decision makers in recognizing engagement level of managers and based upon this information, motivating and helping them generate possible ways and strategies correspondingly for better results.

\section{Future Studies}

Future research could investigate the effect of Herzberg's motivating factors on manager engagement and retention and then put forward a comparison of both hygiene \& motivating factors and discover the largest impact on engagement and retention. This study has some limitations and cannot be generalized to whole population, as the sample size is limited to 122 hotel managers in Turkey. The research results would become more precise if the sample size and the area of study are increased. It cannot be said that engagement and retention are only measured by benefits and services yet there are some other factors that were not taken into account in this study. The detection of the impact of benefits and services on engagement and retention in city and coastal hotels and a comparison between the findings of coastal and city hotels would be helpful for future studies. 


\section{References}

ALLEN, David G.; Shore, Lynn M.; Griffeth, Rodger W., The role of perceived organizational support and supportive human resource practices in the turnover process, Journal of management, 2003, 29.1: 99-118.

BASSETT, Jones, et al. Does Herzberg's motivation theory have staying power?, Journal of management development, 2005, 24.10: 929-943.

BASSI, Laurie J.,"Harnessing the power of intellectual capital", Training \& Development, 1997, 51.12: 25-31.

BAUMRUK, Ray. “The missing link: the role of employee engagement in business success", Workspan, 2004, 47.11: 48-52.

BIRT, M.; Wallis, T.; Winternitz, G., Talent retention in a changing workplace, South African Journal of Business Management, 2004, 35.2.

BRISLIN, Richard W., et al., Evolving Perceptions of Japanese Workplace Motivation An EmployeeManager Comparison, International Journal of Cross Cultural Management, 2005, 5.1: 87-104.

BRITT, Thomas W.; Adler, Amy B.; Bartone, Paul T., Deriving benefits from stressful events: the role of engagement in meaningful work and hardiness, Journal of occupational health psychology, 2001, 6.1: 53 .

BROTHERTON, Bob; Woolfenden, Gerry; Himmetoĝlu, Bülent., Developing human resources for Turkey's tourism industry in the 1990s, Tourism Management, 1994, 15.2: 109-116.

BUCKINGHAM, David, "Young people, politics and news media: beyond political socialization", Oxford Review of Education, 1999, 25(1-2), 171-184

BUCKINGHAM, Marcus; Coffman, Curt, First, break all the rules: What the worlds greatest managers do differently, Simon and Schuster, 1999.

BURKE, Ronald J.; Ng, Eddy, The changing nature of work and organizations: Implications for human resource management, Human Resource Management Review, 2006, 16.2: 86-94.

DECKOP, John R.; Merriman, Kimberly K.; Gupta, Shruti, The effects of CEO pay structure on corporate social performance, Journal of Management, 2006, 32.3: 329-342.

DEVOE, Sanford E.; Iyengar, Sheena S., Managers' theories of subordinates: A cross-cultural examination of manager perceptions of motivation and appraisal of performance, Organizational Behavior and Human Decision Processes, 2004, 93.1: 47-61.

DUBROVSKI, Drago. "The role of customer satisfaction in achieving business excellence", Total quality management, 2001, 12.7-8: 920-925.

EROĞLU, Feyzullah. Davranış Bilimleri, Beta Yayınları, 5. Baskı, İstanbul, 2000.

FITZENZ, Jac. "It's costly to lose good employees", Workforce, 1997, 76.8: 50-51.

FLEMING, John H.; Coffman, Curt; Harter, James K., Manage your human sigma, Harvard business review, 2005, 83.7: 106.

FRANK, Fredric D.; Finnegan, Richard P.; Taylor, Craig R., The race for talent: Retaining and engaging workers in the 21st century, People and Strategy, 2004, 27.3: 12.

GEBAUER, Julie; Lowman, Don, Engagement Gap-Practice the 10 drivers of high engagement, Executive excellence, 2009, 26.4: 5.3

GELB, Joyce, "Feminism, NGOs, and the impact of the new transnationalism.Dynamics of Regulatory Change: How Globalization Affects National Regulatory Policies", 2004, 1: 298.

GUNZ, Hugh; Gunz, Sally, Hired professional to hired gun: An identity theory approach to understanding the ethical behaviour of professionals in non-professional organizations, Human Relations, 2007, 60.6: 851-887. 
HAAR, Jerry; Kossack, Sharon, Employee benefit packages: How understandable are they?, Journal of Business Communication, 1990, 27.2: 185-200.

HARTER, James K.; Schmidt, Frank L.; Hayes, Theodore L., Business-unit-level relationship between employee satisfaction, employee engagement, and business outcomes: a meta-analysis, Journal of applied psychology, 2002, 87.2: 268 .

HERZBERG,F. The motivation to work, Holy Wiley \& Sons, New York, 1959.

HILTROP, Jean-Marie, "The quest for the best: human resource practices to attract and retain talent", European Management Journal, 1999, 17.4: 422-430.

INELMEN, Kivanc; Zeytinoglu, Isik U.; Uygur, Duygu, Are Millennials a different breed? Turkish hospitality sector frontline employees' intention to stay, Managing the new workforce: International perspectives on the millennial generation, 2012, 181-203.

KAHN, William A., "Psychological conditions of personal engagement and disengagement at work", Academy of management journal, 1990, 33.4: 692-724.

KIM, Jungin; Wiggins, Mary Ellen, Family-Friendly Human Resource Policy: Is It Still Working in the Public Sector?, Public Administration Review, 2011, 71.5: 728-739.

KINNEAR, L.; Sutherland, M., Money is fine but what's the bottom-line?.People Dynamics, 2001, 19.1: 14-19.

KINNEAR, L.; Sutherland, M., Money is fine but what's the bottom-line?, People Dynamics, 2001, 19.1: 14-19.

KYNDT, Eva, et al. Employee retention: Organisational and personal perspectives, Vocations and Learning, 2009, 2.3: 195-215.

LEE, Soo-Young; Hong, Jeong Hwa, Does Family-Friendly Policy Matter? Testing Its Impact on Turnover and Performance, Public Administration Review, 2011, 71.6: 870-879.

LOCKWOOD, Nancy,'Work/life balance: Challenges and solutions", Society for Human Resource Management, 2003.

LOCKWOOD, Thomas; Walton, Thomas, Building design strategy: using design to achieve key business objectives, Skyhorse Publishing, Inc., 2013.

MACCOBY, Eleanor E., "Socialization and developmental change", Child Development, 1984, 317-328.

MAERTZ, Carl P.; Griffeth, Rodger W., Eight motivational forces and voluntary turnover: A theoretical synthesis with implications for research, .Journal of Management, 2004, 30.5: 667-683.

MAIDANI, Ebrahim A. "Comparative study of Herzberg's two-factor theory of job satisfaction among public and private sectors", Public Personnel Management, 1991, 20.4: 441-448.

MALIK, Muhammad Ehsan; Naeem, Basharat, Towards understanding controversy on Herzberg theory of motivation, World Applied Sciences Journal, 2013, 24.8: 1031-1036.

MAY, Douglas R.; Gilson, Richard L.; Harter, Lynn M., The psychological conditions of meaningfulness, safety and availability and the engagement of the human spirit at work, Journal of occupational and organizational psychology, 2004, 77.1: 11-37.

MERCER, R. "Mercer study raises red flags for employer pay and benefit plans", Human Resource Department Management Report, 2003, 5: 8-15.

MEUDELL, Karen; Rodham, Karen, Money isn't everything... or is it? A preliminary research study into money as a motivator in the licensed house sector, International Journal of Contemporary Hospitality Management, 1998, 10.4: 128-132.

MORISHIMA, Motohiro, “The evolution of white-collar human resource management in Japan”, Advances in industrial and labor relations, 1996, 7: 145-176. 
MOTTAZ, Clifford J. “The Relative Importance of Intrinsic and Extrinsic Rewards As Determinants Of Work Satisfaction", The Sociological Quarterly, 1985, 26.3: 365-385.

MUSE, Lori A.; Wadsworth, Lori L., An examination of traditional versus non-traditional benefits, Journal of Managerial Psychology, 2012, 27.2: 112-131.

NEBEKER, Delbert, et al. Airline station performance as a function of employee satisfaction, Journal of Quality Management, 2001, 6.1:29-45.

NELSON, Debra L.; Simmons, Bret L., Health psychology and work stress: A more positive approach. 2003.

ONEN, David; Maicibi, Alhas Nok, The applicability of Herzberg's two-factor theory on the junior nonacademic staff of Makerere University, Makerere Journal of Higher Education, 2004, 1.1: 143-152.

ÖZMEN, Ö.; Katrinli, E.; Atabay, G., Otel İşletmelerinde Çalışan Personelin İşin Özelliklerine ve Kişilik Tiplerine Göre İş Doyumlar, Kuşadası:(21/23 Kasım 1991). 2. Ulusal Turizm Kongresi, 1991.

ÖZTÜRK, Yüksel; Alkış, Hüseyin, Konaklama işletmelerinde çalışanların iş tatmininin ölçülmesi üzerine bir araştırma, Uluslararası Yönetim İktisat ve İşletme Dergisi, 2012, 7.14: 437-460.

PARK, Sung Min "A multi-level analysis of work motivation and organizational socialization: Probing the internalized motivational effects among public managers", AZU2007 Conference, Arizona, 2007

PARKER, Owen; Wright, Liz, Pay and Employee Commitment: The Missing Link-The company that enhances compensation conditions and practices will likely see an improvement in employee commitment, Ivey Business Journal, 2001, 65.3: 70-73.

PERRIN, Tower, "Rewards: the not-so-secret ingredient for managing talent.(Retention)", HR focus, 2003, 80.1: 3-10.

PERRIN, Towers, "Winning strategies for a global workforce: Attracting, retaining and engaging employees for competitive advantage", 2005.

PERRIN, Towers, Ten steps to creating an engaged workforce: Key European findings, Towers Perrin global workforce survey 2005, 2006.

REICHHELD, Frederick F., Loyalty rules!: How today's leaders build lasting relationships, Harvard Business Press, 2001.

RHOADES, Linda; Eisenberger, Robert, Perceived organizational support: a review of the literature, Journal of applied psychology, 2002, 87.4: 698.

RICHMAN, Amy. "Everyone wants an engaged workforce how can you create it" Workspan, 2006, 49.1: 36-9.

ROBERTS, Gary E., et al., Traditional and family-friendly benefits practices in local governments: Results from a national survey, Public Personnel Management, 2004, 33.3: 307-330.

ROBERTS, Gary, "An inventory of family-friendly benefit practices in small New Jersey local governments", Review of Public Personnel Administration, 2000, 20.2: 50-62.

SALTZSTEIN, Alan L.; Ting, Yuan; Saltzstein, Grace Hall, Work-family balance and job satisfaction: The impact of family-friendly policies on attitudes of federal government employees, Public administration review, 2001, 61.4: 452-467.

SHAW, Kieron. "An engagement strategy process for communicators ", Strategic Communication Management, 2005, 9.3:26.

SNIPES, Jeff, "Identifying and cultivating high-potential employees" Chief Learning Officer Magazine, 2005, 4.11: 54-64.

STAUSS, Bernd, et al., Retention effects of a customer club, International Journal of Service Industry Management, 2001, 12.1: 7-19. 
STEMPIEN, Lori R.; Loeb, Roger C. Differences in job satisfaction between general education and special education teachers implications for retention, Remedial and Special education, 2002, 23.5: 258267.

SUTCLIFFE, J.; Schuster, J., Benefits Revisited, Benefits Predicted, Personnel Journal, 1985, 64.9: 62-68.

TAN, Teck Hong; Waheed, Amna, Herzberg's motivation-hygiene theory and job satisfaction in the Malaysian retail sector: The mediating effect of love of money, Asian Academy of Management Journal, 2011, 16.1: 73-94

TENGILIMOĞLU, Dilaver, "Hizmet işletmelerinde liderlik davranışları ile iş doyumu arasındaki ilişkinin belirlenmesine yönelik bir araştırma”, Ticaret ve Turizm Eğitim Fakültesi Dergisi, 2005, 1.24: 2345.

TERERA, Sharon Ruvimbo; Ngirande, Hlanganipai, The impact of rewards on job satisfaction and employee retention, Mediterranean Journal of Social Sciences, 2014, 5.1: 481.

THE GALLUP ORGANIZATION, www.gallup.com, Accessed (28th June 2007)

TSUI, Anne S., et al. Alternative approaches to the employee-organization relationship: does investment in employees pay off?, Academy of Management journal, 1997, 40.5: 1089-1121.

WAGAR, Terry H.; Rondeau, Kent V., Retaining employees in small and medium-sized firms: Examining the link with human resource management, Journal of Applied Management and Entrepreneurship, 2006, 11.2: 3 .

Walker, Joan Leslie, Extended discrete choice models: integrated framework, flexible error structures, and latent variables. 2001 (PhD Thesis. Massachusetts Institute of Technology)

WHITE, Richard A., "Employee preferences for nontaxable compensation offered in a cafeteria compensation plan: An empirical study", Accounting Review, 1983, 539-561.

WIN, H. H. "The importance of intrinsic and extrinsic motivation factors as determinants of nurses's job satisfaction: Empirical Study of Taiwan and Myanmar" National Cheng Kung University, Tainan, Taiwan, 2006. (Unpublished dissertation)

ZINELDIN, Mosad. "Beyond relationship marketing: technologicalship marketing", Marketing Intelligence \& Planning, 2000, 18.1: 9-23. 